\title{
BIBÓ ISTVÁN LÁTHATATLAN ALKOTMÁNYA
}

\author{
Kukorelli István \\ (ELTE ÁJK Alkotmányjogi Tanszék)
}

1. Gyakorta töprenkedem a pesti alsó rakparton, Bibó István „mini” szobra alatt munkába menet elhaladva, vajon mit szólna Csoóri Sándorral szólva a "történelem utolsó úriembere" ma ahhoz, amit onnét lát, vajon hogyan diagnosztizálná a mai elit mintaadó szerepét, közállapotainkat, amit egy szobor felállítása, vagy annak eltávolítása (Nagy Imrére gondolok) is kifejez. Mit szólna Tisza István monumentális szobrához, amely eltakarja előle a parlamenti kilátást? A parlamentét, ahol emléktábla őrzi 1956-os államminiszteri helytállását.

Szigethy Gábor írja az 1956-os Bibó kötet Ônző a strázsán című bevezető tanulmányában:

„Egymaga áll a vártán - eszébe jutott Ady Endre tragikus sóhaja? Őrzők: vigyázzatok a strázsán!"* Azé az Adyé, akit Tisza legszívesebben kiradírozott volna a magyar történelemből. Igaz, Ady sem kímélte Tiszát, „a gyújtogató, csóvás embert", s benne - az egyébként tehetséges államférfiban - a grófi Magyarország, egy megváltoztatandó rendszer szimbólumát látta. ${ }^{* *}$ Azét a rendszerét, amelybe Bibó beleszületett és Adyhoz hasonlóan, ha más eszközökkel is, küzdött annak megváltoztatásán.

Kosáry Domokos, az egyik leghitelesebb történészünk mondta Bibóra emlékezve a két világháború közötti társadalmi rendszerről s a maguk felelősségéről:

„Egy tudatos készülődés folyt, annak érdekében, hogy ezt a szerencsétlen, nyomorult, elavult, ósdi, poros országot civilizált európai, polgári demokráciává alakítsuk át."*** Ennek a fiatal, új reformnemzedéknek volt egyik meghatározó gondolkodója Bibó István is.

Bibó polihisztor tudósként alkotmányjogász is volt, életmúvének mozaikjaiból ragyogóan összerakható egy klasszikus, örökkévalósági klauzulákat is tartalmazó alkotmány. Amely konszenzualitásra és stabilitásra törekszik. Ô maga

* Bibó István (szerk: Szigethy Gábor) (2003): 1956. Holnap Könyvkiadó, Budapest, 12. o.

** Bíró Zoltán (1998): Ady Endre sorsköltészete. Püski, Budapest 1998. 60. o.

*** Kortársak Bibóról. Előadások a Bibó István Szakkollégiumban. (Szerk: Gyarmati György-Kukorelli István). ELTE Bibó István Szakkollégium, Budapest 2009. 22. o. 
biztosan tiltakozna ellene, vagy azt mondaná róla, mint amit az általa is írt 1946. évi I. törvényről, a köztársasági kisalkotmányról, hogy „ez nem tetőtől talpig új", vagyis kész alkotmány.* Előadásomban öt mozaikot emelnék ki az életmúből.

2. Térjünk vissza a parlamentbe az első alkotmánymozaikhoz, nem kronológiai sorrendben haladva! Közismert kép, Bibó István, a törvényes Nagy Imrekormány egyetlen cselekvőképes, magát lemondottnak nem tekintő államminisztere ül az írógépe előtt, nyilatkozatot fogalmaz, tervezetet készít az alkotmányos kibontakozás útjáról. Valójában alkotmánytervezetet ír, amelyben ott van a történelmi helyzet lenyomata, a kompromisszumkeresés, de ott van az alkotmányosság, mint a tartalmi értelemben vett alkotmány örök értékeinek tisztelete is.

1956-os alkotmányjogi programjának sarokpontja az új alkotmánytörvény megalkotása, amelynek alapelvei a következők:

- a parlamentáris köztársaság állam- és kormányformája az 1848. évi III. tc., és az 1946. évi I. tc. alapján,

- a szabad választások, a miniszteri felelősség, a hatalmak elválasztása, a bírói függetlenség,

- a szabadságjogok teljessége, különös figyelemmel a szólás- és sajtószabadságra, továbbá a lelkiismereti és vallásszabadságra. ${ }^{* *}$

Tanulságosak az alkotmányozó hatalomra és az alkotmányvédelemre vonatkozó 1956-os bibói elképzelések is. Októberi „12 pontjában” még az utolsó törvényes szabad választások alapján összeült 1947. évi parlamentet jelöli meg az alkotmányozás alanyaként. Államminiszteri tervezetében - az általános választások előtt - a forradalmi bizottságokra és tanácsokra épülő forradalmi alkotmányozó gyúlés mellett érvel, amely arra hivatott, hogy az alkotmányozás elveit elfogadja, esetleg államfőt választ és mindenképpen választójogi törvényt alkot.***

Az alkotmányos rendszer védelmét a jövendő többpártrendszer viszonylatában fogalmazta meg, amely gondolatrendszerében nem kizárt, hogy korlátozott lett volna, idézem: „....nem indulhat párt, amely ezeket nem fogadja el; e felett a legfelsőbb bíróság - illetve keretében megfelelően szervezett alkotmánybíróság - őrködik."

\footnotetext{
* Bibó István: A magyar demokrácia mérlege. In: Válogatott tanulmányok 1945-1949 (szerk: Vida István). II. kötet. Budapest, Magvető Kiadó, 1986. 167. o.

** Bibó István: A politikai és alkotmányjogi kibontakozás útja (1956. október 30-31.) 1d.: 1. lábjegyzet, 51-56. o.

*** Bibó István: Tervezet a magyar kérdés kompromisszumos megoldására. 69. o.

**** 5. lbjgy. uo. 12. pont. 56. o.
} 
Életmúvét ismerve jól tudjuk, hogy Bibó sokat foglalkozott - pl. Magyary Zoltánnal vitatkozva - a közigazgatással, annak jogszerúségével, demokratizmusával. 1956-os tervezeteiben is kiemelt helyen szerepel a közigazgatás újjászervezése, amely a szakszerűség alapján, a versenyvizsga-rendszer általános bevezetésével történik. A közigazgatásba tömegesen bekerült diplomanélküliek és „gyorsított kiképzéssel kiképzettek" helyzetét kötelező \% megállapításával vélte megoldani. Fontos elképzelése volt a közigazgatás bírói ellenőrzésének visszaállítása.

1956-nak tehát alkotmányjogi jelentősége van, bár jól tudjuk, hogy a történelem esélyt sem adott egy esetleges, „'56-os Bibói alkotmány” elfogadására. Alkotmányos követelmények viszont megfogalmazódtak, és ezek leginkább Bibó István nevéhez, államminiszteri tevékenységéhez köthetők. Ezekhez az alkotmányos elvekhez nyúlt vissza jogfolytonosan az 1989/90-es alkotmányos rendszerváltozás, az 1989. október 23-án, az új nemzeti ünnepen kihirdetett köztársasági alkotmány és az első szabadon választott parlament első törvénye is, amely 1956 előtt tiszteleg.*

\section{Tisztelt Közgyưlés!}

3. Az ember és a polgár jogainak 1789-es francia deklarációja óta tudjuk, hogy „Az olyan társadalomnak, amelyben a jogokat nem biztosították intézményesen és amelyben a hatalmi ágakat nem választották szét, nincs alkotmánya".** Erre rímel a második és a harmadik mozaik: a bibói tízparancsolat, ${ }^{* * *}$ és a hatalommegosztásról tartott, 1947-es akadémiai székfoglaló.****

A szabadságszerető ember politikai tízparancsolata nem más, mint egy nagy, morális emberi jogi deklaráció, amely az egyén és a közösség, az egyén és a közhatalom viszonyáról szól. Múfaját tekintve nagyban hasonlít Az emberi jogok egyetemes nyilatkozatához, amit éppen hetven éve, 1948. december 10-én fogadtak el. Az írógépen írt eredeti levéltári példány fejlécén kézírással ez szerepel:

„1938-40. körül kelt politikai tízparancsolat-próbálkozás.”*****

* 1989. évi XXXI. törvény az Alkotmány módosításáról. Magyar Közlöny 1989. október 23. 74. sz. és 1990. évi. XXVIII. törvény az 1956. októberi forradalom és szabadságharc jelentőségének törvénybe iktatásáról. Magyar Közlöny 42. sz. A vitát ld. még ON 1990. május 2-i alakuló ülés jegyzőkönyve 21-23. o.

** Az emberi jogok dokumentumokban. (Szerk.: Kovács István és Szabó Imre). KJK Budapest, 1976. 117-121. o. 16. cikk. 121. o.

*** A szabadságszerető ember tízparancsolata. In: Bibó Breviarium (Szerk.: Debreczeni József). Alexandra, Budapest 2011. 41-43. o.

**** Azállamhatalmak elválasztása egykor és most. In: Bibó István összegyüjtött írásai 1. (Szerk.: Dénes Iván Zoltán). Kalligram, Budapest 2016. 164-185. o.

***** A szerző az eredeti kéziratot néhányszor átszámozta, átszerkesztette. A 4. pont például később, kézírással került a végső szövegbe. A parancsolatot tehát ő maga is próbálkozásnak tekintette, amely oly korban készült, mikor az ember úgy elaljasult. 3d 11.5111/15. sz. levéltári irat 
Ezt a deklarációt egy prédikátori tehetséggel megáldott, kitûnő kodifikátor készítette. A tízparancsolat nem kifejezetten jogi mú, bár annak is felfogható, nincs szankciója. A jóhiszemú, a közösség erejében és az emberek többségének tisztességében bízó européer credója, imádsága, személyes bibliája ez, amely valamennyiünket belülről vezérel.

A tízparancsolatban rendszeresen visszatér a hatalom, az önkényeskedés és az erőszakoskodás, amihez képest fogalmazódik meg a cselekvő, szabadságszerető ember pozíciója. A tízparancsolat nekünk szól, bátorságra, tartásra biztat, az alattvalói létből kívánja felrázni a cselekvőképtelen és közömbös embert. Alattvalói lét mellett, civil kurázsi nélkül nincs alkotmányos demokrácia. A hatalmat ez a felelős emberi cselekvés humanizálja, teszi ellenőrizhetővé. A bibói „Bill of Rights”-ból könnyen kiolvashatók, nevesíthetők az alapvető jogok. Mindenekelőtt az anyajogok; az emberi méltóság, az emberi szabadság, a diszkrimináció tilalma, az egyesülési és gyülekezési jog, a véleménynyilvánítás szabadsága, a lelkiismereti és vallásszabadság. Az alkotmányos demokrácia legfontosabb összetevői.

4. Az államhatalmak elválasztása egykor és most címú tanulmánya - amelyről oly sokat írtak már - az egyik legfontosabb európai alkotmányos követelményt és demokráciakritériumot értékeli történelmi, jogfilozófiai távlatokban. Az írás zárómondatában az államhatalomnak szolgálattá, erkölcsi feladattá való átnemesítésén töpreng Bibó. A hatalom megnemesítésére, spiritualizálására és tárgyiasítására irányuló évszázados fejlődési tendenciák több más írásában is érdekelték őt. Nézetem szerint az akadémiai székfoglaló a Magyaryval folytatott vitából nőtt ki. Bibót felbosszanthatta Magyary nézete, miszerint „Montesqieunek az állami hatalmak szétválasztásáról szóló tana a közigazgatás aránytalan fejlődésének következtében válságba került." * Állandóan vissza kell térni a hatalomkoncentrációval szemben a hatalomgyakorlás igazságos, emberséges és közösségi céljaihoz. A hatalmat - mindenféle hatalomközpontosítást - újból meg újból jogszerûvé kell tenni és érvényes értékszempontoknak kell alávetni, ez a bibói gondolat lényege.

Másként fogalmazva: a hatalmat, a politikát intézményes, alkotmányos keretek közé kell terelni. A hatalom és annak gyakorlói (például a pártok) nem alkotmány alatti intézmények többé. Bibó mindenekelőtt jogszerü, szolgálatszerü, tegyük hozzá, szakszerú és eredményes hatalomgyakorlási rendszert kívánt megvalósítani.

Magyarország 2011-es Alaptörvénye először a közjogtörténetben tételesen tartalmazza a hatalommegosztás elvét.** A bibói gondolatvilághoz képest az

\footnotetext{
* Magyary Zoltán: A mai közigazgatás lényege és feladatköre címú írását idézi Fábián Adrián: Közigazgatáselmélet címú múvében. Dialóg-Campus, Budapest-Pécs 2011. 134. o.

** Stumpf István: Hatalmi ágak megosztása egykor és most. Világosság, LII. évf. 2013. tavasz-nyár 279-281. o.
} 
elv konkretizálása meglehetősen „light"-osra sikeredett. Ha belenézünk a bibói alkotmányos tükörbe, azt látjuk, hogy a magyar Alaptörvény inkább népszuverenitás, mint hatalommegosztás párti, már-már minden hatalmat a Tisztelt Ház gyakorol, mint 1949-ben. Még a kétharmados többséggel rendelkező parlament is csak annyi hatalmat gyakorolhat, amennyi az alkotmányos hatáskör-elosztásból részére kimért. És tudomásul kéne venni azt, hogy a népet nem leváltva, az alkotmány a szuverén és nem a parlament.

5. Elérkezve a negyedik mozaikhoz, a közigazgatáshoz, Bibó szerint a közigazgatás eredményessége érdekében nem a végrehajtó hatalmat kell erösíteni, hanem a politikum behatását kell csökkenteni a szakszerü, szolgálatszerú és jogszerú közigazgatással szemben. Vallja azt, hogy a közigazgatás túlsúlyba kerülése a végrehajtó hatalom ellenőrzésének új formáit kívánja meg. Számos alkotmányos követelményt állít fel a közigazgatással szemben (különösen ilyen a közigazgatási bíráskodás szerepének erősítése).*

Az Alaptörvény utáni helyzetben látni kell, hogy megérkezett a közigazgatási állam, az erős, cselekvőképes kormány jóval kevesebb fékkel és ellensúllyal rendelkezik. A kontrollmechanizmusok (például a parlamenti ellenőrzés eszközei, a közvetlen demokrácia, az Alkotmánybíróság stb.) léteznek ugyan hatásköri korlátként, de erőtlenek. A többségi elv uralma a paritás, vagy a konszenzualitás helyett jól kivehető például az egyes alkotmányos intézmények tagjainak, vagy vezetőinek legitimációs láncolatában.

6. Ötödik alkotmányos mozaik: Közismert Bibó Erdei Ferenccel jegyzett városmegye-koncepciója, amely a magyar valóságra kívánt építeni egy decentralizáltabb önkormányzati rendszert. ${ }^{* *}$

Gyarmati György ismerteti a Nemzeti Parasztpárt reformjavaslatának lényegét:

- vármegyék helyett városmegyéket kell szervezni önkormányzati alapon, az országot kerületekre kell felosztani,

- a demokratikus szellem és a szakszerúség együttes biztosításának megoldása, hogy az önkormányzati vezetők a népből választott laikusok, akiknek szakmailag jól felkészült közigazgatási alkalmazottak vannak alárendelve,

\footnotetext{
* Bibó István: Jogszerű közigazgatás, eredményes közigazgatás, erős végrehajtó hatalom. In: Válogatott tanulmányok, 1935-1944 (szerk.: Vida István-Nagy Endre). I. kötet Budapest, Magvető Kiadó, 1986. 271-294.

Kukorelli István: A közigazgatás alkotmányossága és demokratizmusa (a Bibó-Magyary-vita) In: A közigazgatás tudományos vizsgálata egykor és ma (szerk.: Fazekas Mariann). Budapest, Gondolat Kiadó, 2011. 76-85.

** A magyar közigazgatás reformja a Nemzeti Parasztpárt javaslatában (1946) In: Bürokrácia és közigazgatási reformok Magyarhonban. (Közreadja: Csizmadia Andor). Gondolat Kiadó, Budapest 1979. 541. o.
} 
- a szakigazgatás minden ágának hozzá kell igazodnia az igazgatás általános szervezetéhez,

- kevesebb hivatal, kevesebb hivatalnok lenne,

- egyszerúsíteni kell a közigazgatási eljárást stb.*

A központi igazgatás decentralizációjára irányuló tervezetet az önkormányzati választásokat is sürgető Bibó István terjesztette a Jogi Reformbizottság elé. A javaslatot a koalíciós pártok különböző politikai megfontolásokból elutasították.

7. Bibó István életművének teljesértékűségéből következően direkt alkotmányjogi témájú írása relatíve kevés említhető, ám az öt kiemelt mozaik mellett funkcionálisan, tanulmányaiban elrejtve az alkotmányjognak szinte minden kérdésével foglalkozott. Érdekelte a választójog, a választási rendszer, értékelte a koalíciós korszak választásait. Foglalkoztatta a jó állam-és kormányforma, különösen a demokratikus Magyarország államformája, az 1946. évi I. törvény, az úgynevezett kisalkotmány.

Szélesebb összefüggésben, de lényegében az egyenjogúságról írt, amikor a nacionalizmus vagy a zsidókérdés gyökereit kutatta.

A szuverenitás és az önrendelkezés a témája nagyformátumú, a nemzetközi államközösségrôl szóló írásának, amelyben az Európai Unió jövője és a csatlakozni kívánó államok szempontjából is számos megfontolandó gondolat található.

Az alkotmányjog tudománya számára mindig izgalmasak maradnak közjogi indíttatású írásai, fejtegetései. Éppen azért, mert nem szaktudós volt, hanem az egész felől, társadalmi összefüggésükben és történelmi logikájukban értékelte az alkotmányjogi elveket és intézményeket.

Az alkotmányjog a politikai-hatalmi viszonyok joga, jól tudta ezt, ugyanakkor mindig jogállamiságon belül gondolkodott. Bibónak rendkívül kimúvelt, a klasszikus európai alkotmányossági eszmékre épülő közjogi kultúrája van. Bibó István alkotmányos ember volt!

Hazafele jövet a pesti alsó rakparton - főként Bibó kurzusok után jókedvúen - tisztelegni szoktam Bibó professzor Úr szobra előtt. Egy alkalommal a közigazgatási állam járőrkocsija félreértette ezt a mozdulatot és megállított.

- Maga mit integet nekünk?

- Nem integetek, tisztelegtem egy Kossuth-téri szobornak.

- Kossuthnak?

- Nem.

- Rákóczinak?

* Gyarmati György: Adalékok egy elmaradt közigazgatási reform elméletéhez 1946. Századok, 1979. 3. sz. 513-548. o. 
- Nem, de innét az nem is látható.

- Tisza Istvánnak?

- Nem.

- Hát akkor kinek?

- Bibó István államminiszternek.

- Hát az meg hol van?

Megmutattam. Visszhangzik azóta is bennem a mondat; hát az meg hol van. Ma Bibó hallgatás, Bibó csend van, bár mondják, mindez beszédes tud lenni. Tisza időszerû, Bibó nem, mondta egy volt Bibó kollégista, közjogi méltóság.

Szégyellem magam helyette is.

Meggyőződésem, hogy Bibó ma is időszerû: egy autokratikus közigazgatási államban különösen. A demokrácia deficitekkel terhelt mai alkotmányos rendszer, amely 1989 óta a 45. alkotmánymódosításnál tart, keskeny vágányon, pengeélen múködik. Bibó üzen ma is, üzen az életmú, a tudós gondolkodási módja, tudományos módszertana, személyisége, a bibói magatartásminta. Bibó alkotmányos elvei, többletjelentéssel megtöltött fogalmai (nevezetesen a félelem, a szabadság kis körei, az emberi méltóság, a hatalom emberarcúvá tétele, a politikai hisztériák elleni fellépés stb.) ma is mérték és mérce.

Bibónak ugyan nincs látható chartális alkotmánya, de alkotmányos kultúrája van. Látható. A látók látják. És értik.

Az előadás elhangzott 2018. december 14-én a Magyar Politikatudományi Társaság Közgyülésén. 